\title{
Pengaruh Perputaran Piutang dan Perputaran Persediaan terhadap Profitabilitas (Studi Empiris pada Perusahaan Sektor Industri Barang Konsumsi yang Terdaftar di BEI Periode 2015-2018)
}

\author{
Yanti*, Mumum Maemunah** \\ *Universitas Buana Perjuangan Karawang, Karawang, Indonesia, yanti@ubpkarawang.ac.id. \\ **Universitas Buana Perjuangan Karawang, Karawang, Indonesia, mumun.maemunah@ubpkarawang.ac.id.
}

Article history:

ABSTRACT

Received 28 Januari 2020

Received in Revised 23 April 2020

Accepted 27 April 2020

Keywords:

Receivable Turnover, Inventory Turnover,

Profitability

\begin{abstract}
The aim of this study is to determine the accounts receivable turnover rate and inventory turnover have an influence on profitability both partially and simultaneously in a company. The object of this study is a consumer goods industry sector manufacturing company that listed on Indonesia Stock Exchange in the period 2015-2017. The type of data in this study is quantitative data. The source of the data in this study is secondary data, in the form of financial report data (balance sheet and income statement) related to variable in this study. The results of this study indicates that accounts receivable turnover has an affect on profitability. While inventory turnover does not affect on profitability. The results of the study simultaneously indicates that accounts receivable turnover and inventory turnover influence together on profitability.
\end{abstract}

Tujuan dari penelitian ini adalah untuk mengetahui tingkat perputaran piutang dan perputaran persediaan memiliki pengaruh terhadap profitabilitas baik secara parsial maupun simultan dalam suatu perusahaan. Obyek penelitian ini adalah perusahaan manufaktur sektor industri barang konsumsi yang terdaftar di Bursa Efek Indonesia pada periode 2015-2017. Jenis data dalam penelitian ini adalah data kuantitatif. Sumber data dalam penelitian ini adalah data sekunder, berupa data laporan keuangan (neraca dan laporan laba rugi) terkait dengan variabel dalam penelitian ini. Hasil penelitian ini menunjukkan bahwa perputaran piutang memiliki pengaruh terhadap profitabilitas. Sedangkan perputaran persediaan tidak mempengaruhi profitabilitas. Hasil penelitian secara bersamaan menunjukkan bahwa perputaran piutang dan perputaran persediaan berpengaruh bersama terhadap profitabilitas. 


\section{PENDAHULUAN}

Perusahaan pada dasarnya memiliki tujuan yang ingin dicapai dalam menjalankan kegiatan operasionalnya. Tujuan utama suatu perusahaan yakni untuk mencapai laba semaksimal mungkin. Dengan perusahaan mencapai laba yang maksimal, maka dapat menjaga kelangsungan hidup perusahaan dan dapat mengembangkan pertumbuhan perusahaan. Kecakapan perusahaan dalam mencapai keuntungan (laba) merupakan kunci kesuksesan perusahaan untuk dapat dikatakan memiliki kinerja yang baik, karena keuntungan (laba) merupakan elemen laporan keuangan yang digunakan sebagai instrumen untuk menilai baik tidaknya kinerja sebuah perusahaan (Abdullah, 2014).

Profitabilitas suatu perusahaan dapat diukur dengan keberhasilan dan keahlian perusahaan dalam memanfaatkan aktiva dan modal kerjanya secara efisien serta produktif (Maula, dkk, 2018; Tirtajaya, 2015). Adapun alat ukur yang dipakai untuk mengukur taraf profitabilitas, diantaranya yaitu return on assets (ROA) dan return on equity (ROE). Sebagian besar investor dan kreditur menggunakan profitabilitas sebagai tolok ukur dalam menilai seberapa efektif perusahaan mengelola sumber-sumber yang dimilikinya, dan juga merupakan bahan pertimbangan utama bagi investor dan kreditur dalam mengambil keputusan baik dalam menginvestasikan dana maupun dalam meminjamkan dana pada suatu perusahaan (Hamzah, 2015). Laba atau profitabilitas dijadikan sebagai patokan untuk pertimbangan khususnya dalam pemberian konpensasi atau bonus, maka dapat menciptakan stimulus kepada manajer dalam mengatur profitabilitas sehingga konpensasi atau bonus yang diharapkan dapat diterima manajemen (Ilya, 2006). Perhatian investor seringkali hanya terpusat pada laba, dan tidak memperhatikan prosedur yang digunakan untuk menghasilkan informasi laba tersebut. Padahal, laporan keuangan rentan terhadap manipulasi, seperti perataan, pengungkitan, dan penurunan laba, serta praktik manajemen laba lainnya.

Fenomena gap penelitian di atas yaitu beberapa penelitian tidak membuktikan pengaruh perputaran piutang dan perputaran persediaan terhadap profitabilitas perusahaan sehingga penelitian ini dikaji lebih lanjut dengan melibatkan perusahaan sektor industri makanan dan minuman periode tahun 2015-2017 karena masih menjadi industri yang diminati oleh investor dalam menginvestasikan portfolio. Penelitian ini bertujuan untuk mengkaji dan membuktikan secara empiris tingkat perputaran piutang dan tingkat perputaran persediaan terhadap profitabilitas pada perusahaan manufaktur sektor industri barang konsumsi yang tercatat di Bursa Efek Indonesia (BEI) periode 2015-2017.

\section{KERANGKA PENELITIAN}

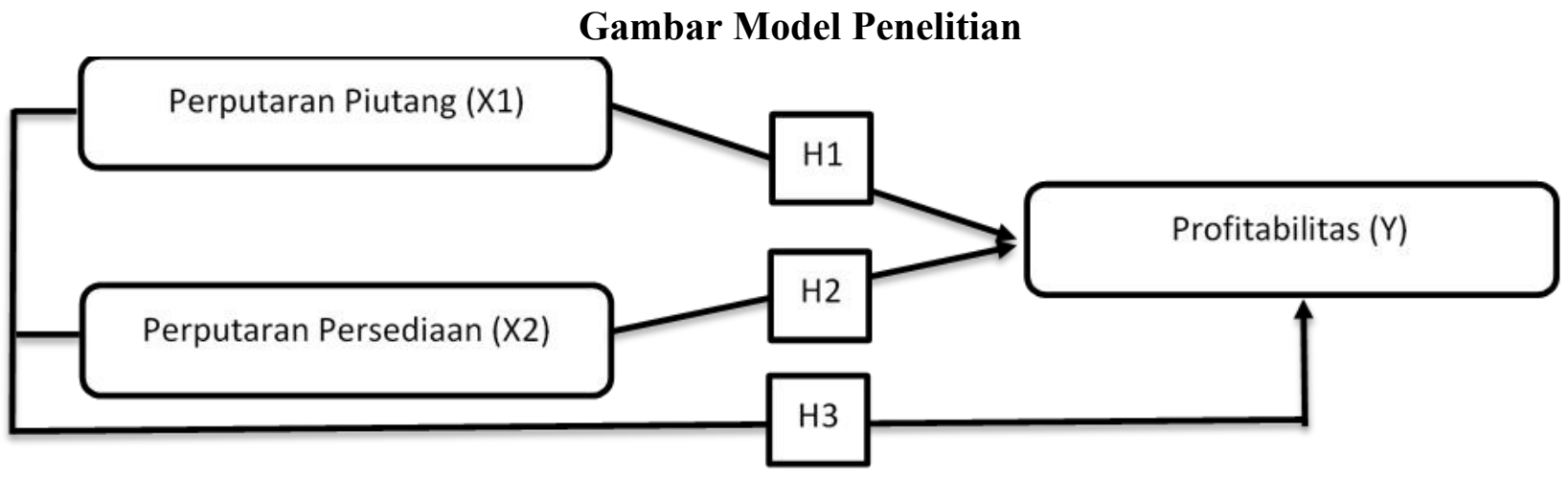

$\mathrm{H} 1=$ Perputaran Piutang berpengaruh signifikan terhadap Profitabilitas

$\mathrm{H} 2=$ Perputaran Persediaan berpengaruh signifikan terhadap Profitabilitas 
H3 = Perputaran Piutang dan Perputaran Persediaan berpengaruh signifikan terhadap Profitabilitas.

\section{METODE PENELITIAN}

Jenis riset ini merupakan penelitian kausalitas yaitu Penelitian yang bertujuan untuk menguji hipotesis tentang pengaruh beberapa variabel independen, yaitu perputaran piutang dan perputaran persediaan terhadap variabel lainnya / variabel dependent yaitu profitabilitas pada perusahaan manufaktur sektor industri barang konsumsi yang terdaftar di Bursa Efek Indonesia. Data yang digunakan dalam penelitian ini adalah data-data kuantitatif yang berupa laporan keuangan perusahaan selama tahun 2014-2017. Teknik penentuan sampel menggunakan metode purposive sampling yaitu teknik penentuan sampel dengan pertimbangan tertentu (Sugiyono, 2015, hal. 126). Sampel perusahaan ditetapkan sebanyak 27 perusahaan yang memenuhi kriteria penelitian. Metode pengumpulan data dengan studi kepustakaan serta dokumentasi di web www.idx.co.id.

- Pengukuran variabel (X1) (Kasmir, 2016), Skala Rasio. dirumuskan:

Perputaran Piutang $=\frac{\text { Penjualan Kredit }}{\text { Rata }- \text { Rata Piutang }}$

- Pengukuran variabel (X2) (Harrison Jr Walter T, 2013), Skala Rasio. dirumuskan:

Perputaran Persediaan $=\frac{\text { Harga Pokok Penjualan }}{\text { Rata }- \text { Rata Persediaan }}$

- Pengukuran variabel (Y) (Kasmir, 2016 hal.136), Skala Rasio. dirumuskan:

Return on Asset $(R O A)=\frac{\text { Laba Seteleh pajak }}{\text { Total Aset }}$

Teknik analisis data menggunakan program SPSS for Windows Ver.24 melalui tahapan berikut ini: (1) Analisis deskriptif berdasarkan sebaran variabel penelitian; (2) Uji asumsi klasik yang terdiri dari uji normalitas, uji heteroskedastisitas, uji multikolinearitas dan uji autokorelasi; (3) Analisis Regresi menggunakan pendekatan linier berganda $Y=a+b_{1} X_{1}+b_{2} X_{2}+\ldots . b_{n} X_{n}$; dan (4) Uji hipotesis melalui analisis koefisien korelasi, koefisien determinasi menggunakan nilai $R$-Square dengan ketentuan Ho ditolak dan Ha diterima jika $\mathrm{t}_{\text {hitung }}>\mathrm{t}_{\text {tabel }}$ (uji parsial) dan $\mathrm{F}$ hitung $>\mathrm{F}$ tabel (uji simultan) serta uji signifikansi parameter individual.

\section{HASIL PENELITIAN DAN PEMBAHASAN}

Variabel Perputaran Piutang menghasilkan koefisien regresi sebesar 0,015 melalui pembuktian hipotesis ke-1 yang menunjukkan bahwa terjadinya pengaruh signifikan atas Perputaran Piutang terhadap Profitabilitas sehingga peningkatan perputaran piutang berdampak terhadap Profitabiltias sebesar 1,5 persen. Hasil ini menjelaskan bahwa piutang muncul karena perusahaan melakukan penjualan secara kredit untuk meningkatkan volume usahanya. Perputaran piutang menunjukkan periode terikatnya modal kerja dalam piutang dimana semakin cepat periode berputarnya menunjukkan semakin cepat perusahaan mendapatkan keuntungan dari penjualan kredit tersebut sehingga profitabilitas perusahaan juga ikut meningkat. Temuan ini membuktikan pengaruh positif atas perputaran piutang terhadap profitabilitas (Kamila, 2017; Lestiowati, 2018) sementara tidak sependapat dengan tidak adanya pengaruh perputaran piutang terhadap profitabilitas (Nuriyani \& Zannati, 2017). 
Variabel Perputaran Persediaan menghasilkan koefisien regresi sebesar -0,012 melalui pembuktian hipotesis ke-2 yang menunjukkan bahwa tidak terjadinya pengaruh signifikan atas Perputaran Persediaan terhadap Profitabilitas sehingga peningkatan atau penurunan perputaran persediaan tidak berdampak terhadap Profitabiltias sebesar minus 1,2 persen. Hasil ini menjelaskan bahwa peningkatan persediaan menjadi indikator akan terjadinya penurunan laba. Di samping itu juga ketika perusahaan menghadapi penjualan yang lambat sementara persediaan terus bertambah akan menambah biaya penyimpanan, resiko kerusakan tinggi dan juga adanya penurunan harga sehingga mengurangi pendapatan penjualan dan laba menjadi rendah. Temuan ini membuktikan tidak terdapatnya pengaruh atas perputaran persediaan terhadap profitabilitas (Surya, dkk 2017) sementara tidak sependapat dengan adanya pengaruh positif atas perputaran persediaan terhadap profitabilitas (Lestiowati, 2018).

Variabel Perputaran Piutang dan Perputaran Persediaan menghasilkan F-hitung sebesar 4,907 dengan probabilitas signifikansi kurang dari 0,05 yaitu 0,010 melalui pembuktian hipotesis ke-3 yang menunjukkan bahwa terjadinya pengaruh signifikan secara simultan atas Perputaran Piutang dan Perputaran Persediaan terhadap Profitabilitas. Temuan penelitian ini sependapat dengan pengaruh simultan atas kedua variabel (Lestiowati, 2018), sementara bertolak belakang dengan kedua variabel (Surya, dkk 2017).

\section{KESIMPULAN}

Berdasarkan hasil penelitian, maka penelitian ini disimpulkan sebagai berikut:

1. Perputaran Piutang berpengaruh signifikan terhadap Profitabilitas

2. Perputaran Persediaan tidak berpengaruh signifikan terhadap Profitabilitas

3. Perputaran Piutang dan Perputaran Persediaan secara simultan berpengaruh signifikan terhadap Profitabiltias

Berdasarkan kesimpulan dari penelitian, maka penelitian ini dapat memberikan saran sebagai berikut:

A. Perluasan sampel penelitian hendaknya ditujukan pada perusahaan industri manufaktur yang terdaftar di Bursa Efek Indonesia (BEI) agar dapat memberikan hasil yang lebih representatif dalam konteks penelitian tentang profitabilitas yang melibatkan faktor perputaran piutang dan perputaran persediaan.

B. Penelitian mendatang hendaknya dapat melibatkan faktor-faktor lainnya untuk lebih dapat mengidentifikasi pengaruh rasio keuangan yang terkait dengan turnover dan lainnya dengan profitabilitas perusahaan.

\section{DAFTAR PUSTAKA}

Abdullah, M. M. (2014). Manajemen dan Evaluasi Kinerja Karyawan. (B. R. Hakim, Ed.) Yogyakarta: Aswaja Pressindo.

Ambarwati, S. D. (2010). Manajemen Keuangan Lanjut. Yogyakarta: Graha Ilmu.

Bulan, T. P. (2015). Pengaruh Modal Kerja terhadap Tingkat Profitabilitas pada PT Adira Dinamika Multi Finance Tbk. Jurnal Manajemen dan Keuangan, 4 (1).

Endarwati, O. (2018, April 23). Industri Makanan dan Minuman Diyakini Terus Cemerlang. Retrieved Mei 10, 2019, from https://ekbis.sindonews.com 
Hamzah, I. R. (2015). Evaluasi Kinerja Keuangan Pada Sektor Industri Konsumsi Dengan Pendekatan Profitabilitas (Studi Kasus Perusahaan Sektor Industri Barang Konsumsi Yang Terdaftar Pada Bursa Efek Indonesia) Periode 2011-2014. Jakarta: FE Universitas Darma Persada.

Harrison Jr Walter T., H. C. (2013). Akuntansi Keuangan (Jilid 2) (8, IFRS ed.). Jakarta: Erlangga. Ilya, A. (2006). Mengungkap Praktik Earnings Management di Perusahan. Jurnal Bisnis Manajemen dan Ekonomi , 7 (3), 828-841.

Kamila, N. F. (2017). Pengaruh Perputaran Piutang Terhadap Profitabilitas (Studi Pada Perusahaan Pertambangan Batu Bara Milik Swasta Yang Terdaftar Di Bursa Efek Indonesia periode 2011-2014). JPAK: Jurnal Pendidikan Akuntansi dan Keuangan, 5 (2), 71-78.

Kasmir, D. (2016). Analisis Laporan Keuangan. Jakarta: PT. Rajagrafindo Persada.

Kementerian Perindustrian RI. (2017). Analisis Perkembangan Industri 2017. Jakarta: Pusat Data dan Industri Kementerian Perindustrian.

Kuntoro. (2007). Metode Statistik. Surabaya: Pustaka Melati.

Lestiowati, R. (2018). Analisis Perputaran Persediaan Dan Perputaran Piutang Terhadap Profitabilitas (Studi Empiris Pada Perusahaan Sektor Makanan dan Minuman Yang Terdaftar di Bursa Efek Indonesia Tahun 2014-2016). Jurnal Akuntansi, 6 (1), 25-39.

Maula, S. A., Tanuatmodjo, H., \& Purnamasari, I. (2018). Dampak Modal Kerja Dalam Peningkatan Profitabilitas Pada Perusahaan Telekomunikasi. Jurnal Strategic, 18 (1), 1222.

Natalia, K. V. dkk (2017). Pengaruh Perputaran Modal Kerja, Perputaran Kas, Perputaran Piutang, dan Perputaran Persediaan terhadap Profitabilitas pada Perusahaan Manufaktur yang Terdaftar di BEI periode tahun 2011-2015. Jurnal Ilmiah Mahasiswa S1 Akuntansi Universitas Pandanaran, 3 (2), 1-17.

Nuriyani, \& Zannati, R. (2017). Pengaruh Perputaran Kas Dan Perputaran Piutang Terhadap Profitabilitas Perusahaan Sub-Sektor Food And Beverages Tahun 2012-2016. Jurnal Riset Manajemen dan Bisnis (JRMB), 2 (3), 425 - 432.

Sapetu, Y. dkk (2017). Pengaruh Manajemen Modal Kerja terhadap Profitabilitas Perusahaan Studi Kasus pada Perusahaan Makanan dan Minuman yang terdaftar di BEI periode 2011-2015. Jurnal EMBA, 5 (2), 1440 -1451.

Sugiyono. (2015). Metode Penelitian Kombinasi (Mixed Methods) (Cetakan ke-5 ed.). (M. Sutopo, Ed.) Bandung: CV. Alfabeta.

Sulistiyawati. (2013). Pengaruh Nilai Perusahaan, Kebijakan Dividen, Dan Reputasi Auditor Terhadap Perataan Laba. Accounting Analysis Journal, 2 (2), 148-153.

Surya, S. dkk (2017). Pengaruh Perputaran Kas dan Perputaran Persediaan. Akuntabilitas: Jurnal Ilmu Akuntansi, 10 (2), 313-332.

Tirtajaya, N. (2015). Pengaruh Perputaran Piutang, Perputaran Persediaan, dan Rasio Lancar Terhadap Profitabilitas Pada Perusahaan Industri Barang Konsumsi Yang Terdaftar di BEI Periode 2012-2014. Jakarta: FE Universitas Dharma Persada.

Warren, C. S. (2016). Pengantar Akuntansi Adaptasi Indonesia. Salemba Empat: Jakarta. 